\title{
PREVENTION AND TREATMENT OF INFECTIOUS COMPLICATIONS POST HSCT
}

\author{
Marcia Garnica Maiolino 1,2, Fabianne Carlesse ${ }^{3,4}$, Jessica Fernandes Ramos ${ }^{5,6}$, Clarisse Martins \\ Machado
}

\begin{abstract}
1 Universidade Federal do Rio de Janeiro - 2 Complexo Hospitalar de Niterói - 3 Universidade Federal de São Paulo
4- nstituto de Oncologia Pediátrica GRAACC - UNIFESP - 5- Hospital das Clínicas - Universidade de São Paulo

6 Hospital Sírio-Libanês - 7 Instituto de Medicina Tropical - Faculdade de Medicina da Universidade de São Paulo

8- Serviço de TMO Hospital Amaral Carvalho - 9 Hospital Albert Einstein - Instituto Israelita de Ensino e Pesquisa
\end{abstract}

Correspondece to: - marciagarnica@hucff.ufrj.br, Fabianne Carlesse - fabiannecarlesse@gmail.com, Jessica Fernandes Ramos - jessicamd39@gmail.com, Clarisse Martins Machado - clarimm@usp.br

\section{INTRODUCTION}

The current version of the "Recommendations for the Prevention and Treatment of post-HSCT Infections" has been structured in tables and divided into the following sessions: 1) pre-transplant screening; 2) prophylactic measures; 3 ) laboratory monitoring; 4) management of febrile neutropenia; 5) empirical and preemptive antimicrobial therapies; 6) antimicrobial therapy for documented infectious events; and 7) post-transplant vaccination program.

In addition to the bibliographic update, new topics were added to the current version, such as the risk stratification for invasive fungal diseases, prophylaxis of CMV infection with letermovir, the debated topic of antibacterial prophylaxis during neutropenia, febrile neutropenia treatment duration, preemptive approach in adenovirus and HHVG infections, and the reemer- gence of yellow fever and measles as a consequence of low vaccine coverage. Concerning the revaccination program, we cite the introduction of PCV13 for adult patients and the recombinant herpes zoster vaccine only for autologous transplant recipients. The latter is currently only available in private vaccination clinics.

Lastly, we would like to highlight the important changes in the management of respiratory viruses due to the COVID-19 pandemic, with the implementation of contact and aerosol precautions in HSCT units. Complete information concerning SARS COV2 and COVID-19 have been posted in the website of SBTMO and has been updated as needed.

The strength of recommendations and quality of evidence were based on the grading system of the European Society of Clinical Microbiology and Infectious Diseases (ESCMID) summarized in

FIGURE 1- Grading system of the ESCMID.

\section{STRENGTH OF RECOMMENDATION}

- Grade A: ESCMID strongly supports the recommendation for use

- Grade B: ESCMID moderately supports the recommendation for use

- Grade C: ESCMID marginally supports the recommendation for use

- Grade D: ESCMID is against the use of the recommendation

\section{QUALITY OF EVIDENCE}

- Level I: evidence from at least one properly designed randomised, controlled trial

- Level II: evidence from at least one well designed clinical trial, without randomization; from cohort or case-controlled analytical studies (preferably from more than one centre); from multiple time series; or from dramatic results of uncontrolled experiments

- Level III: evidence from opinions of respected authorities, based on clinical experience, descriptive case studies, or reports of expert committees 


\begin{tabular}{|c|c|c|}
\hline & 1. PRE-TRANSPLANT SCREENING FOR AUTOLOGOUS OR ALLOGENEIC HSCT & REFERENCES \\
\hline 1.1. & $\begin{array}{l}\text { Assessment: Colonization by a multi-resistant germ (MDR). } \\
\text { Method: Colonization surveillance swab for MDR (MRSA, VRE, CRE, ESBL). } \\
\text { Comment (Evidence): Each center should propose a screening strategy appropriate to its } \\
\text { epidemiology to reduce intra-hospital transmission, in conjunction with the local Infection } \\
\text { Control Program. (BII) }\end{array}$ & [1-3] \\
\hline 1.2. & $\begin{array}{l}\text { Assessment: Previous bacterial infections. } \\
\text { Method: Anamnesis, physical examination, imaging tests, and review of previous events. } \\
\text { Comment (Evidence): Attention to recurrent infectious events, MDR pathogens, and latent } \\
\text { infections. Previous infections by MDR agents will be considered when choosing the } \\
\text { empirical drug at the time of febrile neutropenia (BII) }\end{array}$ & {$[4,5]$} \\
\hline 1.3. & $\begin{array}{l}\text { Assessment: Risk stratification for invasive fungal disease (IFD) } \\
\text { Method:The level of risk for IFD in allogeneic HSCT recipients depends on several factors, } \\
\text { including host characteristics, underlying hematological disease conditions and the type of } \\
\text { transplantation that will be performed. } \\
\text { Anamnesis, physical examination, imaging tests, and review of previous events. } \\
\text { Risk factors: high doses of corticosteroids, prolonged neutropenia, IFD } 6 \text { months before } \\
\text { transplantation. Allogeneic stem cell transplant patients are generally at high risk with } \\
\text { factors such as GVHD, CMV disease, cord blood and haploidentical donors and active } \\
\text { leukemia at time of transplant increasing the risk further. Patients who are not in complete } \\
\text { remission pre-transplant are at higher risk of IFD post-transplant. } \\
\text { Comments (Evidence): Risk stratification identifies those patients who will benefit most } \\
\text { from mold active versus yeast active prophylaxis and those who can be safely managed } \\
\text { with monitoring and clinically driven interventions for IFD (All). }\end{array}$ & [6-13] \\
\hline 1.4 . & $\begin{array}{l}\text { Assessment: Previous viral infection } \\
\text { Method: Medical history and specific serologies (HSV, CMV, EBV, HIV, HCV, HBV, HTLV). } \\
\text { Comments (Evidence): Order HBsAg, anti-HBs, anti-HBc, and anti-HCV serology for } \\
\text { recipient and donor and NAT for the donor. It is crucial to screen viral hepatitis for the right } \\
\text { prophylaxis or treatment (All). }\end{array}$ & {$[4,14]$} \\
\hline 1.5 . & $\begin{array}{l}\text { Assessment: Dengue, Chikungunya Zika. } \\
\text { Method: Inquiry about the epidemiological risk. Serological screening for D / R is not } \\
\text { recommended. } \\
\text { Comment (Evidence): Check whether the candidate and/or donor come from an endemic or } \\
\text { epidemic region; or had a recent travel to such regions. If symptomatic, collect NAT (and/or } \\
\text { NS1 in the case of DENV). If positive, wait } 30 \text { days for stem cell (SC) harvesting or transplant } \\
\text { (All). }\end{array}$ & [15] \\
\hline 1.6. & $\begin{array}{l}\text { Assessment: Screening of respiratory virus infections. } \\
\text { Method: Immunofluorescence assay or multiplex PCR in respiratory samples (nasopharynx } \\
\text { swab or nasal wash) before admission. } \\
\text { Comment (Evidence): With the emergence of COVID-19, the screening of respiratory viruses } \\
\text { in asymptomatic patients became mandatory before admission to HSCT (All). }\end{array}$ & {$[16,17]$} \\
\hline
\end{tabular}




\begin{tabular}{|c|c|c|}
\hline 1.7. & $\begin{array}{l}\text { Assessment: Yellow Fever } \\
\text { Method: There is no recommendation for serological screening for D/R. Consider } \\
\text { vaccinating D and/or R before HSCT. } \\
\text { Comment (Evidence): The whole country has recommendation of yellow fever vaccination. } \\
\text { About } 30 \% \text { of the individuals vaccinated before transplantation maintain antibodies after } \\
\text { HSCT (BII). Check if the donor has been vaccinated recently. If yes, wait } 30 \text { days for SC } \\
\text { harvesting or HSCT. }\end{array}$ & [18-22] \\
\hline 1.8. & $\begin{array}{l}\text { Assessment: Latent tuberculosis infection (LTBI) } \\
\text { Method: Investigate the occurrence of previous TB, TB in household contacts, or diagnose } \\
\text { LTBI by tuberculin skin test (TST) or by interferon gamma release assays (IGRA), e.g., the } \\
\text { QuantiFeron TB test (QTF-TB). } \\
\text { Comment (Evidence): Previous history of TB, contact with TB, positive PPD or reactive } \\
\text { QTF-TB indicate latent TB. Recipient with TST } \geq 5 \mathrm{~mm} \text { is considered reactive (positive). In a } \\
\text { population vaccinated with BCG, the IGRA is recommended because it does not cross-react } \\
\text { with Mycobacterium bovis, present in BCG (BII). }\end{array}$ & {$[23,24]$} \\
\hline 1.9. & $\begin{array}{l}\text { Assessment: Chagas disease } \\
\text { Method: Enzyme immune assay (EIA), immunofluorescent assay (FA) or hemagglutination } \\
\text { inhibition assay (HIA). Perform two different tests. If discordant, repeat with Western blot or } \\
\text { chemiluminescence. } \\
\text { Comment (Evidence): Inquiry D/R about residence in an endemic area, houses that favors } \\
\text { the presence of the vector, blood transfusion before 1992, having family members or a } \\
\text { mother with Chagas positive serology. False negative serology may occur. In such cases, the } \\
\text { information acquired in the survey must be valued and the recipient should be monitored } \\
\text { after HSCT (All). }\end{array}$ & {$[18,25]$} \\
\hline 1.10. & $\begin{array}{l}\text { Assessment: Toxoplasmosis } \\
\text { Method: Toxoplasmosis serology (IgG and IgM) from donor and recipient. } \\
\text { Comment (Evidence): More than } 70 \% \text { of cases are due to reactivation. Higher risk if D-/ } \\
\text { R+. Positive IgM or high levels of IgG may indicate recent infection. In such cases, PCR test } \\
\text { should be performed and if positive, the patient should be treated (All). }\end{array}$ & [26] \\
\hline & $\begin{array}{l}\text { Evaluation: Strongyloidiasis } \\
\text { Method: Investigation by stool examination, and/or serology, or empirical therapy. } \\
\text { Comment (Evidence): In general, the tests have low sensitivity. Empirical pre-HSCT therapy } \\
\text { with ivermectin } 200 \mathrm{mg} / \mathrm{kg} / \mathrm{d} \text { for } 2 \text { days is recommended. Repeat treatment after } 2 \text { weeks. } \\
\text { Alternative schedule is albendazole } 400 \mathrm{mg} 12 / 12 \mathrm{~h} \text { for } 7 \text { days (All). }\end{array}$ & {$[27,28]$} \\
\hline
\end{tabular}


Situation: Antibacterial prophylaxis in the neutropenic phase.

Conduct: Ciprofloxacin or levofloxacin.

Comment (Evidence): The consensus does not recommend using antibacterial prophylaxis in the routine, given the high prevalence of quinolone-resistant enterobacteria and the risk

2.1. of selecting multidrug-resistant strains (MDR). Consider only in centers where the frequency of resistance to quinolones is low $(<30 \%)$, a controlled MDR infection/colonization rate and high bloodstream infection prevalence. In other centers, the benefit is questionable and is not indicated. Antibacterial prophylaxis is not recommended in children during the neutropenia (DI) phase. Caution about QT prolongation toxicity, especially in situations with concomitant use of QT prolongations drugs (as voriconazole)

\begin{tabular}{|l} 
Situation: Antibacterial prophylaxis in late post-engraftment phase. \\
\hline
\end{tabular}

2.2 .

Conduct: Oral penicillin. Alternatives: macrolides, quinolones, or 2nd generation cephalosporins.

Comment (Evidence): Recommended only in patients with GVHD, for preventing S. pneumoniae, or in cases of recurrent respiratory infection and hypogammaglobulinemia. (BII) Immunoglobulin replacement (IVIG) dose $500 \mathrm{mg} / \mathrm{kg} /$ month.

2.3.

Situation: Documented hypogammaglobulinemia (serum lgG $<400 \mathrm{mg} / \mathrm{dl}$ ). Conduct:

need replacement. It is not recommended in patients without documentation of hypogammaglobulinemia. (BIII)

Situation: Primary antifungal prophylaxis (PAP) at High risk

Recommendation: Mold-active PAP is recommended. Posaconazole (Al); voriconazole (BI); caspofungin (CIII); micafungin (CIII).

Children: voriconazole for patients $>2$ years of age (All); or posaconazole in $>13$ years (AII). Alternatives include liposomal amphotericin B (B-II); micafungin (B-II); and, with less strength of evidence, aerosolized liposomal amphotericin B (C-II) and caspofungin (C-II). If posaconazole and voriconazole are selected, TDM is recommended with target concentrations similar to those recommended for adults.

Comment (Evidence): There are 3 phases after the transplant which reflect the risk of IFD: neutropenia (early), a-GVHD and the early immune recovery (late), and late a-GVHD or c-GVHD, together with late immunologic recovery (very late)

High Risk patients (adaptated Girmenia 2014)

Early phase from day 1 to 40: Active acute leukemia at the time of trans- plantation

2.4. (AII), CB transplantation (AII), Grade III-IV a-GVHD after any type of transplantation (AII), Transplantation from MMRD or UD and 1 or more of the following additional risk factors: grade II a-GVHD, steroid dose $>2 \mathrm{mg} / \mathrm{kg} /$ day for at least 1 week, CMV disease, recurrent CMV infection, prolonged neutropenia (PMN $<500 / \mathrm{mL}$ for more than 3 weeks), iron over- load (BIII) , Steroid refractory/dependent a-GVHD after any type of transplantation (AllI).

Late Phase (from day 41 to 100): Acute grade III-IV GVHD after any type of transplantation (All), Transplantation from MMRD or UD and 1 or more of the following additional risk factors: grade II a-GVHD, steroid dose $>2 \mathrm{mg} / \mathrm{kg} /$ day for at least 1 week, CMV disease, recurrent CMV infection, recurrent neutropenia (PMN $<500 / \mathrm{mL}$ for more than 1 week) (BIII), Steroid refractory/dependent a-GVHD after any type of transplantation (AllI)

Very Late Phase after Transplantation (Day > 100) Persistent or late-onset grade III-IV a-GVHD (All), Persistent or late-onset steroid refractory/ dependent a-GVHD after any type of transplantation (All), Persistent or late-onset grade II a-GVHD after transplantation from MMRD or UD (BIII) Extensive c-GVHD when preceded by an a- GVHD (AII)

Situation: Primary antifungal prophylaxis (PAP) at standard risk.

Recommendation: Candida active PAP is recommended.

Fluconazole (Al); voriconazole (BI); micafungin (BI). In children fluconazole (AI). Comment (Evidence): Standard Risk:

2.5. Early Phase after Transplantation (Day 0-40): All remaining patients not included in the highrisk category (Al)

Late Phase after Transplantation (Day 41-100): All remaining patients not included in the highrisk category (BII).

Very Late Phase after Transplantation (Day > 100): Limited c-GVHD in patients who receive only a nonsteroid immunosuppression and "de novo" c-GVHD (BIII). 


\begin{tabular}{|c|c|c|}
\hline 2.6. & $\begin{array}{l}\text { Situation: Primary Antifungal Prophylaxis (PAP) at low risk } \\
\text { Recommendation: No prophylaxis } \\
\text { Comment (Evidence): } \\
\text { Early Phase after Transplantation (Day 0-40). Autologous HSCT: Fluconazole can be used in } \\
\text { the phase of intense neutropenia to prevent Candida infections, especially in the presence of } \\
\text { mucositis. No patient undergoing allogeneic HSCT is considered to be at low risk at this stage } \\
\text { Late Phase after Transplantation (Day } 41-100 \text { ) No patient undergoing allogeneic HSCT may be } \\
\text { considered at low risk for IFD during this phase. } \\
\text { Very Late Phase after Transplantation (Day > 100) Absence of any type of GVHD and no steroid } \\
\text { therapy (All). }\end{array}$ & {$[7,12,45]$} \\
\hline 2.7. & $\begin{array}{l}\text { Situation: Prophylaxis for herpes simplex virus (HSV) and varicella-zoster (VZV). } \\
\text { Recommendation: Acyclovir or Valacyclovir. } \\
\text { Comment (Evidence): Beginning in conditioning up to } 1 \text { year after BMT or up to } 6 \text { months } \\
\text { after the end of immunosuppression, whichever comes last (allogeneic HSCT) (AI). }\end{array}$ & {$[49,50]$} \\
\hline 2.8 & $\begin{array}{l}\text { Situation: Prophylaxis for Cytomegalovirus (CMV). } \\
\text { Recommendation: Letermovir. } \\
\text { Comment (Evidence): Indicated for positive CMV IgG receptors. The benefit is more significant } \\
\text { at high risk: cord, use of post-cyclophosphamide, HLA mismatch, and T cell depletion (e.g., } \\
\text { ATG, alemtuzumab). Perform CMV qPCR before prophylaxis (less effective if DNAemia is } \\
\text { present). Start as soon as possible and keep until D + } 100 \text { (Al). Pay attention to the dose } \\
\text { adjusted for concomitant use of cyclosporine. There is no data in pediatrics for the use of } \\
\text { letermovir. Prophylaxis with acyclovir or valacyclovir for HSV / VZV should be maintained (Al). }\end{array}$ & [51] \\
\hline 2.9. & $\begin{array}{l}\text { Situation: Prophylaxis for HBV } \\
\text { Recommendation: lamivudine; alternative entecavir or tenofovir } \\
\text { Comment (Evidence): Indicated in the following situations: AntiHBC + donor with negative } \\
\text { HBV DNA; AntiHBC / AntiHBs + receptor with negative HBV DNA. For AntiHBC+ receptor with } \\
\text { AntiHBs- and HBV DNA - recommended prophylaxis is entecavir } 0.5 \mathrm{mg} / \text { day. Follow-up with } \\
\text { monthly transaminases when using prophylaxis, if increased, request HBV DNA. Prophylaxis } \\
\text { duration: from the first conditioning day (if not in use) to } 1 \text { year after autologous HSCT } \\
\text { and two years after allogeneic HSCT or six months after the end of immunosuppression } \\
\text { (whichever comes later) (All). }\end{array}$ & {$[14,52]$} \\
\hline 2.10. & $\begin{array}{l}\text { Situation: Prevention of respiratory viruses (RV). } \\
\text { Recommendation: HSCT should be postponed in symptomatic patients (AII). Only patients } \\
\text { who tested negative in pre-HSCT RV screening can be admitted for transplantation (All). } \\
\text { Daily surveillance of respiratory symptoms is crucial (AllI). Rapid diagnosis and precautions } \\
\text { implementation according to specific diagnosis (All). In units with HEPA rooms, the positive } \\
\text { pressure should be reverted or turned off if respiratory viruses are diagnosed (All). } \\
\text { Comment (Evidence): Only recipients of allogeneic HSCT <2 years of age with a high risk of } \\
\text { progression to RSV pneumonia can be considered for treatment with palivizumab (CIII). Due } \\
\text { to the current circulation of SARS CoV- } 2 \text { worldwide, masks and contact precautions besides } \\
\text { hand hygiene is strongly recommended in HSCT units (All). }\end{array}$ & {$[17,53]$} \\
\hline 2.11. & $\begin{array}{l}\text { Situation: Prevention of hemorrhagic cystitis }(\mathrm{HC}) \text { caused by BK virus (BKV). } \\
\text { Recommendation: Hyperhydration (BII) and bladder irrigation (CII). } \\
\text { Comment (Evidence): } \mathrm{HC} \text { prophylaxis is based on hyperhydration and bladder irrigation } \\
\text { to reduce urothelial damage, which occurs mainly in myeloablative conditioning with } \\
\text { cyclophosphamide, busulfan and total body irradiation. Asymptomatic BKV viruria is } \\
\text { frequent after } \mathrm{HSCT} \text { (> } 60 \% \text { ) and there is no correlation between viral load and hematuria } \\
\text { severity. Monitoring of BKV in urine or blood is not recommended. Fluoroquinolones are not } \\
\text { recommended because ineffectiveness in viral replication and severity of } \mathrm{CH} \text {, and the risk of } \\
\text { increasing resistance to quinolones (DII). }\end{array}$ & {$[54,55]$} \\
\hline
\end{tabular}




\begin{tabular}{|c|l|l|}
\hline \multirow{2}{*}{2.12.} & $\begin{array}{l}\text { Situation: Tuberculosis prophylaxis } \\
\text { Management: Prophylaxis with INH for } 6 \text { to } 9 \text { months for recipients with latent TB. An } \\
\text { alternative is to enter prophylaxis if the recipient develops chronic GVHD (BIII). } \\
\text { Comment (Evidence): Prophylaxis with INH has been controversial due to the late occurrence } \\
\text { of TB and adverse events (in general, rare). Main risk factor is chronic GVHD. Maintain } \\
\text { prophylaxis for } 6 \text { months or until the condition stabilizes (BII). }\end{array}$ & {$[56,57]$} \\
\hline 2.13. & $\begin{array}{l}\text { Situation: Prophylaxis for Toxoplasmosis and Pneumocystosis. } \\
\text { Conduct:TMP/SMX. } \\
\text { Comment (Evidence):TMP/SMX is active against T.gondii, P.jiroveci (All adults; Al children), } \\
\text { (All). Half of the cases of toxoplasmosis occur before d+30. Thus, prophylaxis should be started } \\
\text { soon after engraftment and maintained until d+180 or more in patients who continue to } \\
\text { receive IS and/or have chronic GVHD. There is no evidence that prophylaxis can be safely } \\
\text { stopped if CD4+ count is normal (as in HIV +) because other risk factors may persist (BIII). }\end{array}$ & {$[26,58] 5$} \\
\hline
\end{tabular}

\begin{tabular}{|c|c|c|}
\hline & 3. Laboratory monitoring & References \\
\hline 3.1. & $\begin{array}{l}\text { Situation: CMV monitoring. } \\
\text { Method: Perform qPCR (All) or pp65 antigenemia (BII) weekly. } \\
\text { Comment (Evidence): In all CMV seropositive recipients (R+) at least 1x a week up to D + } \\
\text { 100. R- / D- do not require monitoring. CMV monitoring should be done regardless of the } \\
\text { use of prophylaxis with letermovir. CMV monitoring should be prolonged in HSCT with a } \\
\text { mismatch, cord blood or haplo without Pt-Cy; in patients who reactivated up to } d+100 ; \\
\text { who had acute or chronic GVHD; with persistent immunodeficiency or who used prophylaxis } \\
\text { with letermovir. When using qPCR, monitoring should be carried out keeping the same } \\
\text { type of sample, the same method of DNA extraction and quantification (including WHO } \\
\text { quantification standard) (All), and the results must be available within } 48 \text { hours. Monitoring } \\
\text { with AG should start after engraftment. }\end{array}$ & [59] \\
\hline 3.2 & $\begin{array}{l}\text { Situation: Monitoring of EBV. } \\
\text { Method: quantitative PCR (qPCR) weekly } \\
\text { Comment (Evidence): Recommended for groups at risk for post-HSCT lymphoproliferative } \\
\text { disease (DLPT): cord, HLA mismatch; in vivo or in vitro depletion of T cells; mismatch in EBV } \\
\text { serology; splenectomy and previous HSCT (AII). Monitoring starts in D+7 until D+100; may } \\
\text { be extended, at least monthly, in case of GVHD using ISS or previous reactivation of EBV } \\
\text { during the first year (BII). }\end{array}$ & [60] \\
\hline 3.3. & $\begin{array}{l}\text { Situation: Monitoring of HHV- } 6 \text { reactivation. } \\
\text { Method: quantitative PCR (qPCR) } \\
\text { Comment (Evidence): Routine HHV-6 DNA screening is not recommended for pre-emptive or } \\
\text { prophylactic therapy (DII) }\end{array}$ & [86] \\
\hline 3.4 . & $\begin{array}{l}\text { Situation: Adenovirus monitoring (ADV). } \\
\text { Method: qPCR in feces or blood weekly. } \\
\text { Comment (Evidence): In high-risk groups e.g., children with cord blood HSCT or unrelated, } \\
\text { severe GVHD (grade III-IV); severe lymphopenia ( }<200 / L) \text { (IIA children). Adults with cord or } \\
\text { haploidentical HSCT; Severe GVHD (grade III-IV); severe lymphopenia }(<200 / L) ; \text { alemtuzumab } \\
\text { treatment (BII adults). } \\
\text { In feces, viral load above } 106 \text { copies/gram of feces predicts viremia and indicates the time } \\
\text { to start blood monitoring. In the absence of stool screening, blood monitoring can begin } \\
\text { immediately after transplantation and be maintained until D + } 100 \text { (BIII children, CIII adults). }\end{array}$ & [61] \\
\hline
\end{tabular}




\begin{tabular}{|c|c|c|}
\hline 3.5. & $\begin{array}{l}\text { Situation: Aspergillosis } \\
\text { Method: Serum Galactomannan (GM) by EIA, 2-3x/week during the early engraftment phase } \\
\text { has a high sensitivity and negative predictive value (NPV) for IA (AII). Serial screening is not } \\
\text { recommended in patients on mold-active prophylaxis (DII). Children: GM testing can be used } \\
\text { both as a screening tool in pediatric patients considered at high risk for developing IA (B-II) } \\
\text { as well as a diagnostic tool in pediatric patients suspected of having developed IA, e.g. those } \\
\text { with clinical symptoms or imaging abnormalities (B-II). } \\
\text { Comments (Evidence): Better performance of the test with } 2 \text { consecutives values above } \\
0.5 \text { (AI). Monitoring should be combined with imaging tests and clinical evaluation. After } \\
\text { grafting, the risk of developing IFD by filamentous fungus is associated with GVHD and } \\
\text { the use of corticosteroids. Serum monitoring is not recommended in patients who have } \\
\text { filamentous fungus prophylaxis. (DII). Decrease of the ODI during the first two weeks of } \\
\text { antifungal therapy is a reliable predictor of a satisfactory response in cancer patients }\end{array}$ & {$[46,62-69]$} \\
\hline 3.6. & $\begin{array}{l}\text { Situation: Control of response to the treatment of invasive aspergillosis (All) } \\
\text { Method: Galactomannan (GM) by EIA, 2-3x/week } \\
\text { Comments (Evidence): In monitoring response to the treatment of invasive aspergillosis; } \\
\text { the persistence of positive GM is indicative of a poor prognosis. The } 1.3 \text { beta D glucan } \\
\text { test may be positive for several agents such as Candida, Aspergillus, P. jirovecci, without } \\
\text { discriminating between them. }\end{array}$ & [62] \\
\hline 3.7. & $\begin{array}{l}\text { Situation: Monitoring of Chagas disease } \\
\text { Method: Qualitative PCR in decreasing frequency. } \\
\text { Comment (Evidence): In D+ and/or R+ for Chagas. PCR monitoring should start on } \\
\text { admission, then weekly for } 2 \text { months, every other week between } 2 \text { and } 6 \text { months of HSCT } \\
\text { and annually after } 6 \text { months. If benznidazole is introduced pre-emptively, monitor marrow } \\
\text { and hepatic toxicity. There is no benefit of prophylaxis compared to preemptive therapy } \\
\text { (BIII). }\end{array}$ & {$[18,25]$} \\
\hline
\end{tabular}

\begin{tabular}{|c|c|c|}
\hline & 4. Febrile neutropenia (FN) management & References \\
\hline 4.1. & $\begin{array}{l}\text { Situation: Diagnosis of febrile neutropenia. } \\
\text { Method: Fever surveillance, clinical investigation, and blood culture collection. Comment } \\
\text { (Evidence): During neutropenia, monitor for fever or other signs or symptoms suggestive of } \\
\text { infection-detailed clinical examination, identifying signs of sepsis, infectious foci. Blood } \\
\text { culture collections are mandatory before the start of antimicrobials (All). }\end{array}$ & [70] \\
\hline 4.2 . & $\begin{array}{l}\text { Situation: Introduction of empirical antimicrobials. } \\
\text { Method: escalating or de-escalating antimicrobials. Escalation = monotherapy with } \\
\text { piperacillin-tazobactam, or cefepime, or ceftazidime. De-escalation = } \beta \text {-lactam }+ \\
\text { aminoglycoside; } \beta \text {-lactam }+/ \text { - aminoglycoside }+/ \text { - tigecycline; association of polymyxin B / } \\
\text { E; use of new drugs with spectrum for MDR. } \\
\text { Comment (Evidence): An institutional management algorithm appropriate to the local } \\
\text { antimicrobial profile is recommended. Empirical therapy should be started within } 60 \\
\text { minutes after the onset of fever. This measure reduces mortality. If no hemodynamic } \\
\text { instability, history of infection, or previous colonization by MDR pathogen, an escalation } \\
\text { strategy is recommended. Carbapenems as an initial drug are discouraged due to their } \\
\text { association with pseudomembranous colitis. The de-escalation strategy should be used in } \\
\text { clinical instability situations, previous history of MDR, or epidemiological situation of MDR } \\
\text { outbreak in the unit (Al). }\end{array}$ & {$[5,70-77] \mathrm{h}$} \\
\hline
\end{tabular}




\begin{tabular}{|c|c|c|}
\hline 4.3. & $\begin{array}{l}\text { Situation: Criteria for modifying antimicrobial therapy in FN. } \\
\text { Method: Detection of microbiological and / or clinical failure. } \\
\text { Comment (Evidence): Development of new clinical signs or hemodynamic instability } \\
\text { during the initial empirical treatment. Persistent fever in the absence of clinical or } \\
\text { microbiological documentation is not an indication of empirical modification in a stable } \\
\text { patient. Persistent fever should be conducted with an intensification of the diagnostic } \\
\text { approach. Therapy adjustment should be made according to the antibiogram of the } \\
\text { isolated agent. The minimum spectrum of coverage for empirical therapy is enterobacteria } \\
\text { and for Pseudomonas spp (All). }\end{array}$ & {$[71,76,78,79]$} \\
\hline 4.4. & $\begin{array}{l}\text { Situation: Treatment duration in the FN. } \\
\text { Method: Consider the criteria for withdrawal. } \\
\text { Comment (Evidence): The course of antimicrobial treatment should be guided by } \\
\text { documentation of infection and neutrophil recovery }\left(>500 \text { cells } / \mathrm{mm}^{3}\right) \text {. In patients with } \\
\text { fever resolution, no infection documentation, and stability, the empirical therapy may be } \\
\text { suspended after } 3 \text { or } 5 \text { days. In cases of documented infection, the treatment duration will } \\
\text { depend on the type of infection (All). }\end{array}$ & {$[74,80,81]$} \\
\hline
\end{tabular}

\begin{tabular}{|c|c|c|}
\hline \multicolumn{2}{|r|}{ 5. Empiric and Pre-emptive Therapies } & References \\
\hline 5.1. & $\begin{array}{l}\text { Situation: Empiric antifungal therapy } \\
\text { Recommendation: Caspofungin (Al), Lipossomal Amphotericin B (BI), voriconazole (BII) } \\
\text { Comment (Evidence): Empirical therapy is indicated for neutropenic patients who persist } \\
\text { with fever for more than } 4 \text { days using broad spectrum antibiotic therapy at places without } \\
\text { quick access to diagnosis of IFD (e.g., galactomannan) or in high-risk epidemiological } \\
\text { situations. (construction-related outbreaks, etc.). } \\
\text { Children: This approach should be initiates in high-risk neutropenic patients after } 96 \mathrm{~h} \text { of } \\
\text { fever of unclear cause that is unresponsive to broad spectrum antibacterial agents (BII) and } \\
\text { be continued until resolution of neutropenia in the absence of suspected or documented } \\
\text { invasive fungal disease Bll. Four prospective randomized clinical trials have been performed } \\
\text { in pediatric haemato-oncologic populations. }\end{array}$ & [82-85] \\
\hline 5.2 . & $\begin{array}{l}\text { Situation: Pre-emptive antifungal therapy } \\
\text { Recommendation: Voriconazole; isavuconazole. Alternatives: Lipossomal Amphotericin B } \\
\text { or Amphotericin B lipidic complex } \\
\text { Comments (Evidence): The preemptive strategy uses antigenic or molecular fungal markers } \\
\text { (beta } 1.3 \text { glucan, galactomannan, or fungal PCR), surveillance of radiological changes (chest } \\
\text { and sinus CT scans) and clinical data. This treatment strategy has already been shown to } \\
\text { decrease the use of antifungals without impacting mortality related to fungal infection. } \\
\text { The use of biomarkers has limitations in the case of prophylaxis for filamentous fungi, as it } \\
\text { reduces the sensitivity of the test in this situation. False positive results may also occur in } \\
\text { patients with intestinal GVHD and mucositis (adult All, Cl children). } \\
\text { Children: a diagnostic-driven treatment strategy can be recommended in children (A-II) if } \\
\text { the diagnostic infrastructure allows timely access to CT imaging, GM testing and the ability } \\
\text { to undertake bronchoscopies with bronchoalveolar lavage and appropriate microbiologic } \\
\text { assessment. }\end{array}$ & {$[69,86-93]$} \\
\hline 5.3. & $\begin{array}{l}\text { Situation: Preemptive therapy for CMV } \\
\text { Recommendation: Induction therapy with ganciclovir (GCV) or valganciclovir (VGV). } \\
\text { Foscarnet can be used during neutropenia (Al). } \\
\text { Comment (Evidence): Preemptive therapy should be introduced after CMV qPCR positive or } \\
\text { AG positivity ( } \geq 1 \text { positive / } 300,000 \text { cells). The cut-off of the viral load for the introduction } \\
\text { of GCV must be defined locally according to the standardized kit and may vary according } \\
\text { to the patient's risk. High risk = cord, haplo, T cell depletion, and HLA mismatch (lower cut- } \\
\text { off). Low risk = remaining HSCTs or using letermovir (highest cut-off). If viremia is on the } \\
\text { rise after two weeks, consider increasing the dose of GCV (CIII). The duration of preemptive } \\
\text { therapy is } \geq 14 \text { days and maybe suspended after that period with a negative qPCR result. } \\
\text { G-CSF can be used in case of hematopoietic toxicity by GCV. During preemptive therapy, } \\
\text { suspend prophylactic ACV. Oral valganciclovir should not be used in patients with severe GI } \\
\text { GVHD (All) }\end{array}$ & [94] \\
\hline
\end{tabular}




\begin{tabular}{|c|c|c|}
\hline 5.4 & $\begin{array}{l}\text { Situation: Pre-emptive therapy for EBV. } \\
\text { Recommendation: Weaning/withdrawal of immunosuppression (AII). In selected cases, } \\
\text { consider weekly rituximab, from 1-4 doses, until negative EBV qPCR (All). } \\
\text { Comment (Evidence): Post-transplant PTD risk groups are severe acute GVHD (refractory } \\
\text { to corticosteroids), severe chronic GVHD, high or rising EBV viral load, and use of } \\
\text { mesenchymal cells. To date, there are no studies that indicate a viral load cut-off to start } \\
\text { preemptive therapy. Consider the dynamics of EBV viral load. If the viral load is high or } \\
\text { increases, withdraw SI is desirable. If symptoms, or persistence of high CV, start therapy } \\
\text { with rituximab (CIII). }\end{array}$ & {$[60,95]$} \\
\hline 5.5. & $\begin{array}{l}\text { Situation: Pre-emptive therapy for HHV-6. } \\
\text { Recommendation: Consider therapy with GCV or FCV just in few conditions. } \\
\text { Comments (Evidence): Pre-emptive therapy with GCV for } 21 \text { days in risk groups with HHV-6 } \\
\text { positive DNAemia AND compatible neurological condition, excluding other causes, OR } \\
\text { DNAemia with delayed engrafting/myelosuppression with no other explanation (CIII). }\end{array}$ & [96] \\
\hline 5.6. & $\begin{array}{l}\text { Situation: Pre-emptive therapy for ADV. } \\
\text { Recommendation: Reduce immunosuppression (All) and cidofovir therapy (BII). } \\
\text { Comment (Evidence): Patients with disseminated disease could receive therapy with } \\
\text { cidofovir } 3-5 \mathrm{mg} / \mathrm{kg} / \text { week for } 2-3 \text { weeks; after that, every two weeks. Alternative scheme } \\
\text { is cidofovir } 1 \mathrm{mg} / \mathrm{kg} 3 \text { times / week (BII). Hyperhydration and the use of probenecid can } \\
\text { reduce nephrotoxicity. }\end{array}$ & [61] \\
\hline
\end{tabular}

\begin{tabular}{|c|c|c|}
\hline & 6. Antimicrobial therapy for documented infections & References \\
\hline 6.1. & $\begin{array}{l}\text { Situation: Bacterial infections. } \\
\text { Conduct: Clinical and laboratory diagnosis of the disease; specific treatment. } \\
\text { Comment (Evidence): The choice of therapy should be guided by syndrome and } \\
\text { isolated agent (including susceptibility test). There is no indication of expanding the } \\
\text { antimicrobial spectrum beyond what is necessary to treat documented infectious } \\
\text { syndrome in non-neutropenic situations. }\end{array}$ & [97] \\
\hline 6.2 . & $\begin{array}{l}\text { Situation: Candidemia or Acute Invasive Candidiasis } \\
\text { Recommendation: Caspofungin; micafungin; anidulafungin. Alternatives: } \\
\text { Lipossomal Amphotericin B; Amphotericin B lipidic complex or voriconazole. } \\
\text { Comments (Evidence): Therapy should be continued for } 14 \text { days after the first } \\
\text { negative blood culture in the absence of other metastatic foci. Ocular fundoscopy } \\
\text { and echocardiography are recommended for all patients. Central venous catheter } \\
\text { (CVC) should be removed as early as possible when it is the source of infection. } \\
\text { Specie confirmation is necessary to adequate therapy. }\end{array}$ & {$[98,99]$} \\
\hline 6.3. & $\begin{array}{l}\text { Situation: Invasive aspergillosis } \\
\text { Recommendation: Voriconazole (AI); isavuconazole (Al); Lipossomal Amphotericin } \\
\text { B (BII); Amphotericin B lipidid complex (CIII). Children other than neonates: } \\
\text { Voriconazole is recommended as the first line agent to treat IA in all children } \\
\text { except neonates (AII). L-Ampho B -(BII) Caspofungin (CII). Neonates: Lipossomal } \\
\text { Amphotericin B is the first choice in neonates (AllI). } \\
\text { Comments (Evidence): Attention to drug interactions, renal impairment. Treatments } \\
\text { with voriconazole should be monitored by serum voriconazole level. Treatment } \\
\text { duration depends on clinical response and immune reconstitution or recovery from } \\
\text { GvHD. } \\
\text { Regions where the resistance rate is }>10 \% \text { give preference to amphotericin or the } \\
\text { combination of voriconazole and caspofungin. }\end{array}$ & {$[46,62,100-104]$} \\
\hline
\end{tabular}




\begin{tabular}{|c|c|c|}
\hline 6.4. & $\begin{array}{l}\text { Situation: Mucormycosis. } \\
\text { Recommendation: Liposomal Amphotericin B (All); Amphotericin B lipidic complex } \\
\text { (no CNS involvement) (BIII); Isavuconazole (BII) } \\
\text { Posaconazole oral suspension (CII) - not indicated as first therapy, only for post } \\
\text { induction maintenance/secondary prophylaxis. } \\
\text { Comments (Evidence): Local debridement of all necrotic tissue is strongly } \\
\text { recommended. Posaconazole tablets or intravenous are not yet available in Brazil. } \\
\text { Posaconazole is not allowed for children under than } 13 \text { years old. }\end{array}$ & {$[105,106]$} \\
\hline 6.5. & $\begin{array}{l}\text { Situation: Fusariosis } \\
\text { Recommendation: Voriconazole (All); Liposomal Amphotericin B (BII); Amphotericin } \\
\text { B Lipid Complex (CIII); isavuconazole (no data). } \\
\text { Comments (Evidence): Combination therapy can be considered in persistently } \\
\text { neutropenic patients with therapeutic failure. Surgical debridement of localized } \\
\text { lesion should be considered. Monitoring serum levels of voriconazole. Few pediatric } \\
\text { studies, most studies of invasive fusariosis in pediatric immunosuppressed patients } \\
\text { used combination therapy based on azole. }\end{array}$ & [107-111] \\
\hline 6.6. & $\begin{array}{l}\text { Situation: CMV disease } \\
\text { Recommendation: Intravenous Ganciclovir (All); foscarnet (if GCV resistance or } \\
\text { toxicity) (AllI). Alternatives are cidofovir ( } 2 \text { nd line) (BII) or foscarnet + GCV in full } \\
\text { doses (3rd line) (CII). } \\
\text { Comment (Evidence): The addition of intravenous immunoglobulin (IVIG) can be } \\
\text { considered for the treatment of CMV pneumonia (CIII). For other manifestations of } \\
\text { CMV disease, the addition of IgIV (IBD) is not recommended. Intravitreal injections } \\
\text { of GCV or foscarnet can be used to treat CMV retinitis combined with systemic } \\
\text { therapy (BII). Valganciclovir can be used in place of GCV IV or foscarnet, except in } \\
\text { patients with severe gastrointestinal GVHD (BII). Doses need to be adjusted to the } \\
\text { patient's renal function (All). }\end{array}$ & [94] \\
\hline 6.7. & $\begin{array}{l}\text { Situation: Disease due to EBV and PTLD. } \\
\text { Recommendation: Reduce SI and rituximab weekly for up to } 4 \text { weeks (All). An } \\
\text { alternative is the transfer of adaptive immunity by infusion of donor lymphocytes } \\
\text { (DLI) if specific EBV (CII). } \\
\text { Comment (Evidence): In cases of disease (hepatitis, pneumonitis, or CNS disease) } \\
\text { due to suspected or confirmed EBV or PTLD (with biopsy), therapy should be started } \\
\text { as soon as possible (All). Factors of good prognosis are age }<30 \text { years, benign } \\
\text { disease, absence of acute GVHD, reduced ISS at diagnosis, and drop in viremia after } \\
\text { initial therapy. }\end{array}$ & {$[60,95,112,113]$} \\
\hline 6.8. & $\begin{array}{l}\text { Situation: Influenza A or B. } \\
\text { Recommendation: Oseltamivir. } \\
\text { Comment (Evidence): The introduction of oseltamivir is recommended in all } \\
\text { individuals with suspected or documented influenza infection (All). Oseltamivir may } \\
\text { be withdrawn if diagnostic tests rule out influenza. }\end{array}$ & [114] \\
\hline 6.9. & $\begin{array}{l}\text { Situation: Respiratory syncytial virus (RSV) } \\
\text { Recommendation: Supportive therapy consider the use of ribavirin at high risk (BIII). } \\
\text { Consider IVIG as an adjuvant (BIII). } \\
\text { Comment (Evidence): Consider immunodeficiency score for low risk (score } 0-2 \text { ), } \\
\text { medium risk (3-6) and high risk (7-12). The following factors are considered in } \\
\text { the score: neutropenia <500; lymphopenia <200; age }>40 \text {; GVHD using steroids; } \\
\text { myeloablative conditioning and HSCT for }<1 \text { year (BII). High risk of complications } \\
\text { comprises a patient with RSV or RSV pneumonia detected before grafting, } \\
\text { lymphopenia <0.3 x } 109 \text { / L (most important), GVHD using IS, or neutrophils }<0.5 \times \\
109 \text { / L. }\end{array}$ & {$[115,116]$} \\
\hline
\end{tabular}




\begin{tabular}{|c|c|c|}
\hline 6.10. & $\begin{array}{l}\text { Situation: Parainfluenza, adenovirus, metapneumovirus, rhinovirus, coronavirus. } \\
\text { Recommendation: If documented before HSCT, postpone conditioning (BII). } \\
\text { Supportive therapy considers the use of IVIG if hypogammaglobulinemia ( }<400 \mathrm{mg} \\
\text { / dL). } \\
\text { Comment (Evidence): If recurrent or severe respiratory infections with IgG } \\
\text { hypogammaglobulinemia }<400 \mathrm{mg} / \mathrm{dL} \text {, IVIG replacement may be performed. } \\
\text { Perform IgG dosage monthly. }\end{array}$ & [46] \\
\hline 6.11. & $\begin{array}{l}\text { Situation: BK virus hemorrhagic cystitis (BKV). } \\
\text { Recommendation: Supportive treatment. Antiviral treatment is controversial. } \\
\text { Comment (Evidence): There is no effective antiviral for BKV hemorrhagic cystitis. } \\
\text { Treatment is based on supportive therapy (hyperhydration, bladder irrigation, } \\
\text { platelet transfusions to reduce bleeding, and pain management). Treatment with } \\
\text { cidofovir IV is controversial (absence of randomized controlled studies), but it may } \\
\text { be an option although there is uncertainty regarding efficacy, doses, and risk- } \\
\text { benefit in the face of renal side effects. Intravesical cidofovir can be used in severe } \\
\text { cases with evaluation by an ID physician. }\end{array}$ & {$[54,55]$} \\
\hline 6.13. & $\begin{array}{l}\text { Situation: Tuberculosis } \\
\text { Conduct: RHZE for } 2 \text { months + RH } 4 \text { months. In HSCT recipients, therapy may be } \\
\text { prolonged according to clinical response. } \\
\text { Comment (Evidence): The most common form is pulmonary, with symptoms similar } \\
\text { to the immunocompetent host (fever, weight loss and persistent cough). Clinical } \\
\text { suspicion can be masked in patients with lung GVHD (investigate TB always). Acid } \\
\text { fast bacilli (AFB) shows low sensitivity ( } 60 \% \text { ), and culture is the gold standard for TB } \\
\text { diagnosis (but may take } 30 \text { days). Currently, PCR is most recommended yielding fast } \\
\text { results and allowing prompt introduction of treatment. There are molecular tests } \\
\text { that already detect resistance to rifampicin (All). }\end{array}$ & {$[117,118]$} \\
\hline 6.14 . & $\begin{array}{l}\text { Situation: Pneumocystosis. } \\
\text { Conduct: Sulfamethoxazole-trimethoprim. } \\
\text { Comment (Evidence): The consensus recommends diagnostic confirmation } \\
\text { by specific tests. Full dose therapy should be administered for at least } 14 \\
\text { days. Secondary prophylaxis should be maintained for the duration of IS (All). } \\
\text { Corticosteroid use may be necessary in cases of hypoxemia. Alternatives are } \\
\text { pentamidine (BII), primaquine + clindamycin or atovaquone (CIII). }\end{array}$ & [119] \\
\hline 6.15. & $\begin{array}{l}\text { Situation: Toxoplasmosis } \\
\text { Conduct: Sulfadiazine + pyrimethamine for } 4 \text { to } 6 \text { weeks (All). Add leucovorin due to } \\
\text { hematological toxicity of pyrimethamine. } \\
\text { Comment (Evidence): Non-specific presentation. Investigate neurological and } \\
\text { ocular conditions. Other presentations are fever with no apparent cause and } \\
\text { interstitial pneumonia. Diagnosis by PCR for T. gondii or immunohistochemistry in } \\
\text { biopsy or BAL. C-reactive protein or procalcitonin have no role in the diagnosis. }\end{array}$ & {$[26,27]$} \\
\hline
\end{tabular}




\begin{tabular}{|c|c|c|c|c|c|c|}
\hline \multicolumn{6}{|c|}{ 7. POST-TRANSPLANT REVACCINATION PROGRAM } & \multirow{2}{*}{ References (120-123) } \\
\hline \multicolumn{6}{|c|}{ Inactivated vaccines } & \\
\hline Vaccine & Start & Doses & Interval & $\begin{array}{c}\text { Chronic } \\
\text { GVHD }\end{array}$ & Children & Autologous \\
\hline PCV13 & 3-4 mo & 3 & $1 \mathrm{mo}$ & 4th dose & Idem & Idem \\
\hline PPV23 & $12 \mathrm{mo}$ & 1 & $\begin{array}{c}>8 w \text { after } \\
\text { PCV }\end{array}$ & Idem & - & - \\
\hline Hib & 3-4 mo & 3 & $1 \mathrm{mo}$ & Idem & Idem & Idem \\
\hline DTP-Hib & $6 \mathrm{mo}$ & 3 & $1 \mathrm{mo}$ & Idem & Idem & Idem \\
\hline MCV & $6 \mathrm{mo}$ & 2 & $1 \mathrm{mo}$ & Idem & Idem & Idem \\
\hline DTaP & $6 \mathrm{mo}$ & 3 & $1-2 \mathrm{mo}$ & Idem & Idem & Idem \\
\hline IPV & $6 \mathrm{mo}$ & 3 & $1-2 \mathrm{mo}$ & Idem & Idem & Idem \\
\hline INF & $6 \mathrm{mo}$ & 1 & Annually & 2 doses & 2 doses $(<9 y r)$ & Idem \\
\hline $\mathrm{HBV}$ & $6 \mathrm{mo}$ & 3 & $0-1-6 \mathrm{mo}$ & Idem & Idem & Idem \\
\hline HAV & 6-12 mo & 2 & $6 \mathrm{mo}$ & Idem & Idem & Idem \\
\hline HPV & 6-12 mo & 3 & $0-2-8 \mathrm{mo}$ & Idem & Idem & Idem \\
\hline HZV rec & d50-d70 & 2 & $1-2$ meses & $\operatorname{Rec}$ & inant vaccine. & utologous HSCT \\
\hline
\end{tabular}

\begin{tabular}{|c|c|c|c|c|c|c|}
\hline \multicolumn{7}{|c|}{ ATTENUATED VACCINES } \\
\hline Vaccine & Start & Doses & Interval & Chronic GVHD & Children & Autologous \\
\hline LAVV & $24 \mathrm{mo}$ & 1 & $1 \mathrm{~m}$ & Contraindicated & 2 doses & Idem \\
\hline LAZV & \multicolumn{6}{|c|}{ Contraindicated in HSCT recipients } \\
\hline MMR & $24 \mathrm{mo}$ & 1 & $1 \mathrm{~m}$ & Contraindicated & 2 & Idem \\
\hline YFV & $24 \mathrm{mo}$ & 1 & - & Contraindicated & $>9$ meses & Idem \\
\hline
\end{tabular}




\section{OTHER SPECIFIC COMMENTS}

\begin{tabular}{|c|c|}
\hline PCV13 & $\begin{array}{l}\text { At Reference Centers for Special Immunobiological Agents (CRIEs) and at Basic Health Units (UBS), } \\
\text { children under } 5 \text { yr may receive PCV10. In private clinics, PCV13 is preferred. In patients with } \\
\text { chronic GVHD, a 4th dose of PCV13 may be administered } 6 \text { months after the 3rd dose. In general, } \\
\text { children respond better to PCV13, but have more fever and local reactions than adults (AI). }\end{array}$ \\
\hline PPV23 & $\begin{array}{l}\text { Those who have already received PPV23, can take } 1 \text { dose of PCV13 after } \geq 6 \text { months. If } \\
\text { gammaglobulinemia }<3 \mathrm{~g} / \mathrm{L} \text {, severe GVHD, or rituximab for less than } 6 \mathrm{~m} \text {, maintain with } \\
\text { prophylactic antibiotics + IgIV and wait to perform PPV23 (BI). }\end{array}$ \\
\hline $\mathrm{Hib}$ & $\begin{array}{l}\text { Cord blood and non-myeloablative transplantation have the same response rate (BII). Chronic } \\
\text { GVHD does not interfere in the response (AII). }\end{array}$ \\
\hline DTaP & The adult formulation (dTaP) is poorly immunogenic. Use DTaP for adults and children (BII). \\
\hline INF & $\begin{array}{l}\text { Annually, for life, or at least up to } 6 \mathrm{~m} \text { after the end of IS. Children }<9 \text { years at the first } \\
\text { vaccination or those with chronic GVHD should receive } 2 \text { doses (one month apart) (All). }\end{array}$ \\
\hline HAV & $\begin{array}{l}\text { Serology (lgG) is recommended to evaluate specific antibodies and the need of vaccination. } \\
\text { More than } 90 \% \text { of HSCT recipients maintain antibodies for up to } 5 \text { years. The response to HAV } \\
\text { vaccine in HSCT recipients is poor }(\sim 30 \%) \text { (CII). }\end{array}$ \\
\hline HBV & $\begin{array}{l}\text { R-/D-: vaccinate after } 6-12 \text { months of HSCT. } \\
R-/ D \text { antiHBC }+ \text { : vaccinate before HSCT }(0-10-21) \text { and give } \mathrm{HBIg}(\mathrm{BII}) \text {. } \\
\mathrm{R} \text { antiHBC }+ \text { : vaccinate after } 6 \text { months of } \mathrm{HSCT} \text {. If anti-HBs }+ \text {, monitor monthly and vaccinate if } \\
\text { anti-HBs }<10 \mathrm{mIU} / \mathrm{mL} \text { (BIII). } \\
\text { In children, attention to the pediatric dose of the vaccine. Age and chronic GVHD decrease the } \\
\text { response to HBV vaccine. }\end{array}$ \\
\hline HZV rec & So far, only approved for autologous HSCT (AI). \\
\hline Attenuated vaccines & Only after $24 \mathrm{~m}$ of HSCT and in patients without IS and without chronic GVHD. \\
\hline LAVV & $\begin{array}{l}\text { More than } 90 \% \text { of HSCT recipients have had zoster after the } 2 \text { nd year of HSCT. Therefore, } \\
\text { chickenpox vaccine would benefit only a few patients (DII). The attenuated varicella vaccine } \\
\text { may be indicated in children ( } 2 \text { doses) and in VZV seronegative adults ( } 1 \text { dose). }\end{array}$ \\
\hline MMR & $\begin{array}{l}\text { In case of measles outbreak, MMR can be anticipated to the 12th month of HSCT and in patients } \\
\text { with mild IS (BII). }\end{array}$ \\
\hline YFV & $\begin{array}{l}\text { To date, there are no reports of serious adverse events in HSCT recipients vaccinated against YF. } \\
\text { Consider vaccination before transplantation, since } 30 \% \text { of vaccinees maintain antibodies after } \\
\text { HSCT (BIII). }\end{array}$ \\
\hline
\end{tabular}




\section{REFERENCES}

1.Ruhnke M, Arnold R, Gastmeier P. Infection control issues in patients with haematological malignancies in the era of multidrug-resistant bacteria. Lancet Oncol. v.15, n. 13, p. 606-19, 2014.

2.Satlin MJ, Chavda KD, Baker TM, Chen L, Shashkina E, Soave R, et al. Colonization with Levofloxacin-resistant Extended-spectrum $\beta$-Lactamase-producing Enterobacteriaceae and Risk of Bacteremia in Hematopoietic Stem Cell Transplant Recipients. Clin Infect Dis. v. 67, n. 11, p. 1686-7, 2018.

3.Webb BJ, Healy R, Majers J, Burr Z, Gazdik M, Lopansri B, et al. Prediction of bloodstream infection due to vancomycin-resistant enterococcus in patients undergoing leukemia induction or hematopoietic stem-cell transplantation. Clin Infect Dis. v.64, n.12,p. 1753-9, 2017.

4.Tomblyn M, Chiller T, Einsele H, Gress R, Sepkowitz K, Storek J, et al. Guidelines for preventing infectious complications among hematopoietic cell transplantation recipients: a global perspective. Biol Blood Marrow Transplant. v.15, n.10, p. 1143-238, 2009.

5.Kamboj $M$, Cohen N, Huang $Y$, Kerpelev $M$, Jakubowski A, Sepkowitz KA, et al. Impact of Empiric Treatment for Vancomycin-Resistant Enterococcus in Colonized Patients Early after Allogeneic Hematopoietic Stem Cell Transplantation. Biol Blood Marrow Transplant. v. 25, n. 3, p. 594-8, 2019.

6.Douglas AP, Slavin MA. Risk factors and prophylaxis against invasive fungal disease for haematology and stem cell transplant recipients: an evolving field. Expert Rev Anti Infect Ther. v. 14, n. 12, p. 1165-77, 2016.

7.Girmenia C, Barosi G, Piciocchi A, Arcese W, Aversa F, Bacigalupo A, et al. Primary Prophylaxis of Invasive Fungal Diseases in Allogeneic Stem Cell Transplantation: Revised Recommendations from a Consensus Process by Gruppo Italiano Trapianto Midollo Osseo (GITMO). Biol Blood Marrow Transplant. v. 20, n.8, p. 1080-8, 2014.

8.Corzo-León DE, Satlin MJ, Soave R, Shore TB, Schuetz AN, Jacobs SE, et al. Epidemiology and outcomes of invasive fungal infections in allogeneic haematopoietic stem cell transplant recipients in the era of antifungal prophylaxis: a single-centre study with focus on emerging pathogens. Mycoses. v. 58, n. 6, p. 325-36, 2015.
9.Martino R, Parody R, Fukuda T, Maertens J, Theunissen $\mathrm{K}, \mathrm{Ho} A$, et al. Impact of the intensity of the pretransplantation conditioning regimen in patients with prior invasive aspergillosis undergoing allogeneic hematopoietic stem cell transplantation: a retrospective survey of the Infectious Diseases Working Party of the Euro. Transplantation. v. 108, n. 9, p. 2928-36, 2006.

10.Parody R, Martino R, Rovira M, Vazquez L, Vázquez MJ, de la Cámara $R$, et al. Severe Infections after Unrelated Donor Allogeneic Hematopoietic Stem Cell Transplantation in Adults: Comparison of Cord Blood Transplantation with Peripheral Blood and Bone Marrow Transplantation. Biol Blood Marrow Transplant. v. 12, n. 7, p. 734-48, 2006.

11.Liu YC, Chien SH, Fan NW, Hu MH, Gau JP, Liu $\mathrm{CJ}$, et al. Incidence and risk factors of probable and proven invasive fungal infection in adult patients receiving allogeneic hematopoietic stem cell transplantation. J Microbiol Immunol Infect. v. 49, n. 4, p. 567-74, 2016.

12.Choi JK, Cho SY, Yoon SS, Moon JH, Kim SH, Lee $\mathrm{JH}$, et al. Epidemiology and Risk Factors for Invasive Fungal Diseases among Allogeneic Hematopoietic Stem Cell Transplant Recipients in Korea: Results of "RISK" Study. Biol Blood Marrow Transplant. v. 23, n.10, p. 1773-9, 2017.

13.Cesaro S, Tridello G, Castagnola E, Calore E, Carraro $\mathrm{F}$, Mariotti I, et al. Retrospective study on the incidence and outcome of proven and probable invasive fungal infections in high-risk pediatric onco-hematological patients. Eur J Haematol. v. 99, n. 3, p. 240-8, 2017.

14.Mallet V, van Bömmel F, Doerig C, Pischke S, Hermine $O$, Locasciulli $A$, et al. Management of viral hepatitis in patients with haematological malignancy and in patients undergoing haemopoietic stem cell transplantation: Recommendations of the 5th European Conference on Infections in Leukaemia (ECIL-5). Lancet Infect Dis. v. 16, n. 5, p. 606-17, 2016.

15.Carvalho AM de SA, Machado CM. Emerging Tropical Viral Infections: Dengue, Chikungunya, and Zika. In: Emerging Transplant Infections. Cham: Springer International Publishing; $p$. 1-24, 2020.

16.Coll E, Fernández-Ruiz $M$, Sánchez-Álvarez JE, Martínez-Fernández JR, Crespo M, Gayoso J, et 
al. COVID-19 in transplant recipients: The Spanish experience. Am J Transplant. Nov 10;ajt. p. $16369, .2020$.

17.Machado CM. COVID-19 and hematopoietic stem cell transplantation: recommendations from the Brazilian Society of Bone Marrow Transplantation (SBTMO). JBMTCT. v. 1, n. 1, p. 67-72, 2020.

18.Machado CM, Martins TC, Colturato I, Leite MS, Simione AJ, De Souza MP, et al. Epidemiology of neglected tropical diseases in transplant recipients. Review of the literature and experience of a Brazilian HSCT center. Vol. 51, Revista do Instituto de Medicina Tropical de Sao Paulo. . v. 51, p. 309-24, 2009.

19.Adler M, Lapierre V, Sakr R, Bourhis JH, Gachot $B$, Castilla-Llorente $C$, et al. Persistence ofyellow fever immunization-induced antibodies in allogeneic hematopoietic stem cell transplant recipients. J Infect Dis. v. 217, n. 11, p. 1844-5, 2018.

20.Avelino-Silva VI, Freire M da S, Rocha V, Rodrigues CA, Novis YS, Sabino EC, et al. Persistence of Yellow Fever vaccine-induced antibodies after cord blood stem cell transplant. Hum Vaccines Immunother. v. 12, n.4, p. 937-8, 2016.

21.Sicre De Fontbrune F, Arnaud C, Cheminant M, Boulay A, Konopacki J, Lapusan S, et al. Immunogenicity and Safety of Yellow Fever Vaccine in Allogeneic Hematopoietic Stem Cell Transplant Recipients after Withdrawal of Immunosuppressive Therapy. J Infect Dis. v.217, n.3, p. 494-7, 2018.

22. Hayakawa K, Takasaki T, Tsunemine H, Kanagawa S, Kutsuna S, Takeshita N, et al. Persistent seropositivity for yellow fever in a previously vaccinated autologous hematopoietic stem cell transplantation recipient. Int J Infect Dis. v. 37, p. 9-10, 2015.

23.Tomblyn M, Chiller T, Einsele H, Gress R, Sepkowitz K, Storek J, et al. Guidelines for preventing infectious complications among hematopoietic cell transplantation recipients: a global perspective. Biol Blood Marrow Transplant. v.15, n.10, p. 1143-238, 2009.

24.Centers for Disease Control. Targeted tuberculin testing and treatment of latent tuberculosis infection. American Thoracic Society. Morb Mortal Wkly Rep. v. 49, p. 1-51, 2000.
25.Pinazo MJ, Miranda B, Rodríguez-Villar C, Altclas J, Serra MB, García-Otero EC, et al. Recommendations for management of Chagas disease in organ and hematopoietic tissue transplantation programs in nonendemic areas. Transplant Rev. v. 25, n.3, p. 91-101, 2011.

26.Prestes DP, Mendes C, Batista M V., Ramos JF, Junior JS, Okay TS, et al. A case-series of Toxoplasmosis in hematopoietic stem cell transplantation: still a concern for endemic countries. Bone Marrow Transplant. v. 53, n.10, p. 1336-9, 2018.

27.Peixoto D, Prestes DP. Parasitic Infections of the Stem Cell Transplant Recipient and the Hematologic Malignancy Patient, Including Toxoplasmosis and Strongyloidiasis. Infect Dis Clin North Am. v. 33, n. 2, p. 567-91, 2019.

28.Jarque I, Salavert M, Pemán J. Parasitic infections in hematopoietic stem cell transplantation. Mediterr J Hematol Infect Dis. v. 8, n. 1, p. 1-15, 2016.

29.Bucaneve G, Micozzi A, Menichetti F, Martino P, Dionisi MS, Martinelli G, et al. New England Journal. World Health. p. 877-89, 2005.

30.Gafter-Gvili A, Paul M, Fraser A, Leibovici L. Effect of quinolone prophylaxis in afebrile neutropenic patients on microbial resistance: Systematic review and meta-analysis. J Antimicrob Chemother. v. 59, n.1, p. 5-22, 2007.

31.Wingard JR, Eldjerou L, Leather H. Use of antibacterial prophylaxis in patients with chemotherapy-induced neutropenia. Curr Opin Hematol. 2012 Jan; v. 19, n. 1, p. 21-6, 2012.

32.Mikulska M, Cordonnier C. Fluoroquinolone prophylaxis during neutropenia: what can we expect nowadays? Clin Microbiol Infect. v. 24, n. 7, p. 678-9, 2018..

33.Lehrnbecher T, Fisher BT, Phillips B, Alexander $S$, Ammann RA, Beauchemin M, et al. Guideline for antibacterial prophylaxis administration in pediatric cancer and hematopoietic stem cell transplantation. Clin Infect Dis. v. 71, n. 1, data, p. 226-36, 2020.

34.Kimura $M$, Araoka $H$, Yoshida A, Yamamoto $H$, Abe $M$, Okamoto $Y$, et al. Breakthrough viridans streptococcal bacteremia in allogeneic hematopoietic stem cell transplant recipients receiving levofloxacin prophylaxis in a Japanese hospital. BMC Infect Dis. v.16, n.1, p. 1-10, 2016. 
35.Signorelli J, Zimmer A, Liewer S, Shostrom VK, Freifeld A. Incidence of Febrile Neutropenia in Autologous Hematopoietic Stem Cell Transplant (HSCT) Recipients on levofloxacin prophylaxis. Transpl Infect Dis. v. 22, n.2, 12apr. 2020.

36.Ricci E, Mesini A, Bandettini R, Faraci M, Castagnola E. Antibacterial prophylaxis of febrile neutropenia is not effective in the pre-engraftment period in pediatric allogeneic hematopoietic stem cell transplantation. Transpl Infect Dis. v. 22, n. 5, 2020.

37.Sokos DR, Berger M, Lazarus HM. Intravenous immunoglobulin: appropriate indications and uses in hematopoietic stem cell transplantation. Biol Blood Marrow Transplant. v. 8, n.3, p. 117-30, 2002.

38. Howell JE, Gulbis AM, Champlin RE, Qazilbash $\mathrm{MH}$. Retrospective analysis of weekly intravenous immunoglobulin prophylaxis versus intravenous immunoglobulin by IgG level monitoring in hematopoietic stem cell transplant recipients. Am J Hematol. v. 87, n. 2, p. 172-4, 2012.

39.Derman BA, Schlei Z, Parsad S, Mullane K, Knoebel RW. Changes in Intravenous Immunoglobulin Usage for Hypogammaglobulinemia After Implementation of a Stewardship Program. JCO Oncol Pract. 2020 Aug 21;OP.20.00312.

40.Ullmann A, Lipton JH, Vesole DH, Chandrasekar P, Langston A, Tarantolo S. Posaconazole or Fluconazole for Prophylaxis in Severe Graft-versusHost Disease. N Engl J Med. v. 356, n.4, p. 335-47, 2007.

41.Fleming S, Yannakou CK, Haeusler GM, Clark J, Grigg $\mathrm{A}$, Heath $\mathrm{CH}$, et al. Consensus guidelines for antifungal prophylaxis in haematological malignancy and haemopoietic stem cell transplantation, 2014. Intern Med J. v. 44, n. 12, p. 1283-97, 2014.

42.Fukuda T, Boeckh M, Carter RA, Sandmaier BM, Maris MB, Maloney DG, et al. Risks and outcomes of invasive fungal infections in recipients of allogeneic hematopoietic stem cell transplants after nonmyeloablative conditioning. Blood. v. 102, n.3, p. 827-33, 2003.

43.Girmenia C, Raiola AM, Piciocchi A, Algarotti A, Stanzani $M$, Cudillo $L$, et al. Incidence and outcome of invasive fungal diseases after allogeneic stem cell transplantation: A prospective study of the gruppo italiano trapianto midollo osseo (GITMO). Biol Blood Marrow Transplant. v. 20, n. 6, p. 872-80, 2014.

44.Matsumura-Kimoto Y, Inamoto Y, Tajima K, Kawajiri A, Tanaka T, Hirakawa T, et al. Association of Cumulative Steroid Dose with Risk of Infection after Treatment for Severe Acute Graft-versusHost Disease. Biol Blood Marrow Transplant. v. 22, n.6, p. 1102-7, 2016.

45.Lehrnbecher T, Fisher BT, Phillips B, Beauchemin $M$, Carlesse F, Castagnola E, et al. Clinical practice guideline for systemic antifungal prophylaxis in pediatric patients with cancer and hematopoietic stem-cell transplantation recipients. J Clin Oncol. v. 38, n. 27, p. 3205-16, 2020.

46.Warris A, Lehrnbecher T, Roilides E, Castagnola E, Brüggemann RJM, Groll AH. ESCMID-ECMM guideline: diagnosis and management of invasive aspergillosis in neonates and children. Clin Microbiol Infect. v.38, n. 27, p. 1096-113, 2019.

47.Garcia-Vidal C, Upton A, Kirby KA, Marr KA. Epidemiology of Invasive Mold Infections in Allogeneic Stem Cell Transplant Recipients: Biological Risk Factors for Infection According to Time after Transplantation. Clin Infect Dis. v. 47, n. 8, p. 1041-50, 2008.

48.Wingard JR, Carter SL, Walsh TJ, Kurtzberg J, Small TN, Baden LR, et al. Randomized, double-blind trial of fluconazole versus voriconazole for prevention of invasive fungal infection after allogeneic hematopoietic cell transplantation. Blood.v.116, n. 24, p. 5111-8, 2010.

49.Erard V, Guthrie K a, Varley C, Heugel J, Wald A, Flowers MED, et al. One-year acyclovir prophylaxis for preventing varicella-zoster virus disease after hematopoietic cell transplantation: no evidence of rebound varicella-zoster virus disease after drug discontinuation. Blood.v. 110, n. 8, p. 3071-7, 2007.

50.Thomson KJ, Hart DP, Banerjee L, Ward KN, Peggs KS, Mackinnon S. The effect of low-dose aciclovir on reactivation of varicella zoster virus after allogeneic haemopoietic stem cell transplantation. Bone Marrow Transplant. v. 35, n. 11, p. 1065-9, 2005.

51.Marty FM, Ljungman P, Chemaly RF, Maertens J, Dadwal SS, Duarte RF, et al. Letermovir Prophylaxis for Cytomegalovirus in Hematopoietic-Cell Transplantation. N Engl J Med. 2017;NEJMoa 1706640. 
52.Sarmati L, Andreoni M, Antonelli G, Arcese W, Bruno R, Coppola N, et al. Recommendations for screening, monitoring, prevention, prophylaxis and therapy of hepatitis $B$ virus reactivation in patients with haematologic malignancies and patients who underwent haematologic stem cell transplantation-a position paper. Clin Microbiol Infect. v. 23, n. 12, p. 935-40, 2017.

53.Hirsch HH, Martino R, Ward KN, Boeckh M, Einsele $\mathrm{H}$, Ljungman P. Fourth European conference on infections in leukaemia (ECIL-4): Guidelines for diagnosis and treatment of human respiratory syncytial virus, parainfluenza virus, metapneumovirus, rhinovirus, and coronavirus. Clin Infect Dis. v. 56, n. 2, p. 258-66, 2013.

54.Lunde LE, Dasaraju S, Cao Q, Cohn CS, Reding M, Bejanyan N, et al. Hemorrhagic cystitis after allogeneic hematopoietic cell transplantation: risk factors, graft source and survival. Bone Marrow Transplant. v. 50, n. 11, p. 1432-7, 2015.

55.Cesaro S, Dalianis T, Rinaldo $\mathrm{CH}$, Koskenvuo $\mathrm{M}$, Pegoraro A, Einsele $\mathrm{H}$, et al. ECIL guidelines for the prevention, diagnosis and treatment of $\mathrm{BK}$ polyomavirus-associated haemorrhagic cystitis in haematopoietic stem cell transplant recipients. J Antimicrob Chemother. v. 73, n. 1, p. 12-21, 2018.

56. Yang A, Shi J, Luo Y, Ye Y, Tan Y, Huang H, et al. Allo-HSCT recipients with invasive fungal disease and ongoing immunosuppression have a high risk for developing tuberculosis. Sci Rep. v. 9, n.1, p. 1-7, 2019.

57.Lee H-J, Lee D-G, Choi S-M, Park SH, Cho S-Y, Choi J-K, et al. The demanding attention of tuberculosis in allogeneic hematopoietic stem cell transplantation recipients: High incidence compared with general population. PLoS One. v. $12 \mathrm{~m}$, n.3, p. 0173250, 2017.

58. Maertens J, Cesaro S, Maschmeyer G, Einsele H, Donnelly JP, Alanio A, et al. ECIL guidelines for preventing Pneumocystis jirovecii pneumonia in patients with haematological malignancies and stem cell transplant recipients. J Antimicrob Chemother. v. 71, p. 1-8, 2016.

59.Ljungman P, de la Camara R, Robin C, Crocchiolo R, Einsele H, Hill JA, et al. Guidelines for the management of cytomegalovirus infection in patients with haematological malignancies and after stem cell transplantation from the 2017
European Conference on Infections in Leukaemia (ECIL 7). Lancet Infect Dis. v. 19, n. 8, p. 60-72, 2019.

60.Styczynski J, van der Velden W, Fox CP, Engelhard D, de la Camara R, Cordonnier C, et al. Management of Epstein-Barr Virus infections and post-transplant lymphoproliferative disorders in patients after allogeneic hematopoietic stem cell transplantation: Sixth European Conference on Infections in Leukemia (ECIL-6) guidelines. Haematologica. v. 101, n. 7, p. 803-11, 2016.

61.Matthes-Martin S, Feuchtinger T, Shaw PJ, Engelhard D, Hirsch HH, Cordonnier C, et al. European guidelines for diagnosis and treatment of adenovirus infection in leukemia and stem cell transplantation: Summary of ECIL-4 (2011). Transpl Infect Dis. v. 14, n. 6, p. 555-63, 2012.

62.Ullmann AJ, Aguado JM, Arikan-Akdagli S, Denning DW, Groll AH, Lagrou K, et al. Diagnosis and management of Aspergillus diseases: executive summary of the 2017 ESCMID-ECMM-ERS guideline. Clin Microbiol Infect. v. 24, p. 1-38, 2018.

63.Castagnola E, Furfaro E, Caviglia I, Licciardello $M$, Faraci M, Fioredda $F$, et al. Performance of the galactomannan antigen detection test in the diagnosis of invasive aspergillosis in children with cancer or undergoing haemopoietic stem cell transplantation. Clin Microbiol Infect. v.16, n.8. p. 1197-203, 2010.

64.Fisher BT, Zaoutis TE, Park JR, Bleakley M, Englund JA, Kane C, et al. Galactomannan antigen testing for diagnosis of invasive aspergillosis in pediatric hematology patients. J Pediatric Infect Dis Soc. v.1, n.2, p. 2012.

65.Choi S-H, Kang E-S, Eo H, Yoo S-Y, Kim JH, Yoo $\mathrm{KH}$, et al. Aspergillus galactomannan antigen assay and invasive aspergillosis in pediatric cancer patients and hematopoietic stem cell transplant recipients. Pediatr Blood Cancer. v. 60, n. 2, p. 316-22, 2013.

66.Jha AK, Bansal D, Chakrabarti A, Shivaprakash MR, Trehan A, Marwaha RK. Serum galactomannan assay for the diagnosis of invasive aspergillosis in children with haematological malignancies. Mycoses. v.56, n.4, p. 66-73, 2013.

67.Dinand V, Anjan M, Oberoi JK, Khanna S, Yadav SP, Wattal C, et al. Threshold of galactomannan antigenemia positivity for early diagnosis of in- 
vasive aspergillosis in neutropenic children. $J$ Microbiol Immunol Infect. v. 49. n. 1, p. 2016.

68.Marr KA, Laverdiere M, Gugel A, Leisenring W. Antifungal therapy decreases sensitivity of the Aspergillus galactomannan enzyme immunoassay. Clin Infect Dis. v. 40, n. 12, p. 1762-9, 2005.

69.Groll AH, Castagnola E, Cesaro S, Dalle J-H, Engelhard D, Hope W, et al. Fourth European Conference on Infections in Leukaemia (ECIL-4): guidelines for diagnosis, prevention, and treatment of invasive fungal diseases in paediatric patients with cancer or allogeneic haemopoietic stem-cell transplantation. Lancet Oncol. v. 15, p. 327-40, 2014.

70.Lehrnbecher T, Robinson P, Fisher B, Alexander $S$, Ammann RA, Beauchemin $M$, et al. Guideline for the management of fever and neutropenia in children with cancer and hematopoietic stemcell transplantation recipients: 2017 update. $J$ Clin Oncol. v.35, n.18, p. 2082-94, 2017.

71.Averbuch D, Cordonnier C, Livermore DM, Mikulska M, Orasch C, Viscoli C, et al. Targeted therapy against multi-resistant bacteria in leukemic and hematopoietic stem cell transplant recipients: Guidelines of the 4th European conference on Infections in Leukemia (ECIL-4, 2011). Haematologica. v. 98, n.12, p. 1836-47, 2013.

72.Bow EJ, Rotstein C, Noskin G a, Laverdiere M, Schwarer a $\mathrm{P}$, Segal $\mathrm{BH}$, et al. A randomized, open-label, multicenter comparative study of the efficacy and safety of piperacillin-tazobactam and cefepime for the empirical treatment of febrile neutropenic episodes in patients with hematologic malignancies. Clin Infect Dis. v. 43, n.4, p. 447-59, 2006.

73.Paul M, Yahav D, Fraser A, Leibovici L. Empirical antibiotic monotherapy for febrile neutropenia: Systematic review and meta-analysis of randomized controlled trials. J Antimicrob Chemother. v. 57, n. 2, p. 176-80, 2006.

74.Aguilar-Guisado M, Espigado I, Martín-Peña A, Gudiol C, Royo-Cebrecos C, Falantes J, et al. Optimisation of empirical antimicrobial therapy in patients with haematological malignancies and febrile neutropenia (How Long study): an open-label, randomised, controlled phase 4 trial. Lancet Haematol. v. 4, n.12, p. 573-83, 2017.

75.Kochanek M, Schalk E, von Bergwelt-Baildon M,
Beutel G, Buchheidt D, Hentrich M, et al. Management of sepsis in neutropenic cancer patients: 2018 guidelines from the Infectious Diseases Working Party (AGIHO) and Intensive Care Working Party (iCHOP) of the German Society of Hematology and Medical Oncology (DGHO). Ann Hematol. v. 98, n.5, p. 1051-69, 2019.

76.Goodlet KJ, Nicolau DP, Nailor MD. In vitro comparison of ceftolozane-tazobactam to traditional beta-lactams and ceftolozane-tazobactam as an alternative to combination antimicrobial therapy for Pseudomonas aeruginosa. Antimicrob Agents Chemother. v. 61, n.12, p. 1-12, 2017.

77.Ogura S, Kimura M, Takagi S, Mitsuki T, Yuasa M, Kageyama K, et al. Characteristics of gram-negative bacteremia during febrile neutropenia among allogeneic hematopoietic stem cell transplant recipients on levofloxacin prophylaxis. Eur J Clin Microbiol Infect Dis. 2020 Nov 13;

78.Perreault S, McManus D, Bar N, Foss F, Gowda $\mathrm{L}$, Isufi I, et al. The impact of a multimodal approach to vancomycin discontinuation in hematopoietic stem cell transplant recipients (HSCT) with febrile neutropenia (FN). Transpl Infect Dis. v. 21, v.2, p. 13059, 2019.

79.Wang L, Wang Y, Fan X, Tang W, Hu J. Prevalence of Resistant Gram-Negative Bacilli in Bloodstream Infection in Febrile Neutropenia Patients Undergoing Hematopoietic Stem Cell Transplantation. Med (United States). v. 94, n. 45, p. 1931, 2015.

80.Gustinetti G, Raiola AM, Varaldo R, Galaverna F, Gualandi F, Del Bono V, et al. De-Escalation and Discontinuation of Empirical Antibiotic Treatment in a Cohort of Allogeneic Hematopoietic Stem Cell Transplantation Recipients during the Pre-Engraftment Period. Biol Blood Marrow Transplant. v. 24, n.8, p. 1721-6, 2018.

81.Rearigh L, Stohs E, Freifeld A, Zimmer A. De-escalation of empiric broad spectrum antibiotics in hematopoietic stem cell transplant recipients with febrile neutropenia. Ann Hematol. v.99, n.8, p. 1917-6, 2020.

82.Sandler ES, Mustafa MM, Tkaczewski I, Graham ML, Morrison VA, Green M, et al. Use of amphotericin B colloidal dispersion in children.J Pediatr Hematol Oncol. v. 22, n.3, p. 242-6.

83. Maertens JA, Madero L, Reilly AF, Lehrnbecher $\mathrm{T}$, Groll $\mathrm{AH}$, Jafri HS, et al. A randomized, dou- 
ble-blind, multicenter study of caspofungin versus liposomal amphotericin B for empiric antifungal therapy in pediatric patients with persistent fever and neutropenia. Pediatr Infect Dis J. v.29, n. 5, p. 415-20, 2010.

84.Caselli D, Cesaro S, Ziino O, Ragusa P, Pontillo A, Pegoraro A, et al. A prospective, randomized study of empirical antifungal therapy for the treatment of chemotherapy-induced febrile neutropenia in children. Br J Haematol. v. 158, n.2, p. 249-55, 2012.

85.Prentice HG, Hann IM, Herbrecht R, Aoun M, Kvaloy $S$, Catovsky D, et al. A randomized comparison of liposomal versus conventional amphotericin B for the treatment of pyrexia of unknown origin in neutropenic patients. $\mathrm{Br} J$ Haematol. v. 48, n. 8, p. 711-8, 1997.

86.Cordonnier C, Pautas C, Maury S, Vekhoff A, Farhat $\mathrm{H}$, Suarez $\mathrm{F}$, et al. Empirical versus preemptive antifungal therapy for high-risk, febrile, neutropenic patients: a randomized, controlled trial. Clin Infect Dis. v. 48, n. 8, p. 1042-51, 2009.

87.Girmenia C, Micozzi A, Gentile G, Santilli S, Arleo $\mathrm{E}$, Cardarelli $\mathrm{L}$, et al. Clinically driven diagnostic antifungal approach in neutropenic patients: $\mathrm{A}$ prospective feasibility study. J Clin Oncol. v. 28, n.4, p. 667-74, 2010.

88.Pagano L, Caira M, Nosari A, Cattaneo C, Fanci R, Bonini $A$, et al. The use and efficacy of empirical versus pre-emptive therapy in the management of fungal infections: The HEMA e-Chart project. Haematologica. v. 96, n. 6, p. 1366-70, 2011.

89.Delgado-Araneda M, Valenzuela R, Maza V, Rabello M, Álvarez AM, Contardo V, et al. Usefulness of serum galactomannan in initiating and modifying antifungal therapy in children with cancer and persistent high-risk febrile neutropenia. Mycoses. v. 63, n.8, p. 802-11, 2020.

90.Tan BH, Low JGH, Chlebicka NL, Kurup A, Cheah FK, Lin RTP, et al. Galactomannan-guided preemptive vs. empirical antifungals in the persistently febrile neutropenic patient: A prospective randomized study. Int J Infect Dis. v. 15, n 5, p. 350-6, 2011.

91.Yuan W, Ren J, Guo X, Guo X, Cai S. Preemptive antifungal therapy for febrile neutropenic hematological malignancy patients in China. Med Sci Monit. v. 22, p. 4226-32, 2016.
92.Santolaya $\mathrm{ME}$, Alvarez $A M$, Acuña $M$, Avilés $C L$, Salgado C, Tordecilla J, et al. Efficacy of pre-emptive versus empirical antifungal therapy in children with cancer and high-risk febrile neutropenia: A randomized clinical trial. $J$ Antimicrob Chemother. v. 73, n.10, p. 2860-6, 2018.

93.Castagnola E, Bagnasco F, Amoroso L, Caviglia I, Caruso S, Faraci M, et al. Role of Management Strategies in Reducing Mortality From Invasive Fungal Disease in Children With Cancer or Receiving Hemopoietic Stem Cell Transplant. Pediatr Infect Dis J. v.33, n.3, p. 233-7, 2014.

94.Ljungman $\mathrm{P}$, de la Camara R, Robin C, Crocchiolo R, Einsele H, Hill JA, et al. Guidelines for the management of cytomegalovirus infection in patients with haematological malignancies and after stem cell transplantation from the 2017 European Conference on Infections in Leukaemia (ECIL 7). Lancet Infect Dis. v.19, n.8, p. 260-72, 2019.

95.Trappe R, Oertel S, Leblond V, Mollee P, Sender $M$, Reinke $P$, et al. Sequential treatment with rituximab followed by $\mathrm{CHOP}$ chemotherapy in adult B-cell post-transplant lymphoproliferative disorder (PTLD): the prospective international multicentre phase 2 PTLD-1 trial. Lancet Oncol. v.104, n. 11, p. 196-206, 2012.

96.Ward KN, Hill JA, Hubacek P, De La Camara R, Crocchiolo $R$, Einsele $H$, et al. Guidelines from the 2017 European Conference on Infections in Leukaemia for management of HHV-6 infection in patients with hematologic malignancies and after hematopoietic stem cell transplantation. Haematologica. v.104, n. 11, p. 2155-63, 2019.

97.Tatarelli P, Mikulska M. Multidrug-resistant bacteria in hematology patients: emerging threats. Future Microbiol. v. 11, n.6, p. 767-80, 2016.

98.Pappas PG, Kauffman CA, Andes DR, Clancy CJ, Marr KA, Ostrosky-Zeichner L, et al. Clinical Practice Guideline for the Management of Candidiasis: 2016 Update by the Infectious Diseases Society of America. Clin Infect Dis. v.62, n.4, p. 1-50, 2015.

99.Tissot F, Agrawal S, Pagano L, Petrikkos G, Groll AH, Skiada A, et al. ECIL-6 guidelines for the treatment of invasive candidiasis, aspergillosis and mucormycosis in leukemia and hematopoietic stem cell transplant patients. Haematologica. v. 102, n. 3, p. 433-44, 2017. 
100.Maertens JA, Raad II, Marr KA, Patterson TF, Kontoyiannis DP, Cornely OA, et al. Isavuconazole versus voriconazole for primary treatment of invasive mould disease caused by Aspergillus and other filamentous fungi (SECURE): a phase 3, randomised-controlled, non-inferiority trial. Lancet. v. 387, p. 100-90, 2016.

101.Patterson TF, Thompson GR, Denning DW, Fishman JA, Hadley S, Herbrecht R, et al. Executive summary: Practice guidelines for the diagnosis and management of aspergillosis: 2016 update by the infectious diseases society of America. Clin Infect Dis. v. 63, n.4, p. 433-42, 2016.

102. Herbrecht R, Denning DW, Patterson TF, Bennett JE, Greene RE, Oestmann J-W, et al. Voriconazole versus amphotericin B for primary therapy of invasive aspergillosis. Vol. 347, The New England journal of medicine. v. 347, 2002.

103.Denning DW, Ribaud P, Milpied N, Caillot D, Herbrecht R, Thiel E, et al. Efficacy and Safety of Voriconazole in the Treatment of Acute Invasive Aspergillosis. Clin Infect Dis. v. 34, n.5, p. 563-71, 2002.

104.Walsh TJ, Lutsar I, Driscoll T, Dupont B, Roden $M$, Ghahramani P, et al. Voriconazole in the treatment of aspergillosis, scedosporiosis and other invasive fungal infections in children. Pediatr Infect Dis J. v.21, n.3, p. 240-8, 2002.

105.Cornely OA, Alastruey-Izquierdo A, Arenz D, Chen SCA, Dannaoui E, Hochhegger B, et al. Global guideline for the diagnosis and management of mucormycosis: an initiative of the European Confederation of Medical Mycology in cooperation with the Mycoses Study Group Education and Research Consortium. Lancet Infect Dis. n. 12, p. 405-21, 2019.

106.Marty FM, Ostrosky-Zeichner L, Cornely OA, Mullane KM, Perfect JR, Thompson GR, et al. Isavuconazole treatment for mucormycosis: a single-arm open-label trial and case-control analysis. Lancet Infect Dis. v. 16, n.7, p. 288-37, 2016.

107.Tortorano AM, Richardson $M$, Roilides $E$, van Diepeningen A, Caira M, Munoz P, et al. ESCMID and ECMM joint guidelines on diagnosis and management of hyalohyphomycosis: Fusarium spp., Scedosporium spp. and others. Clin Microbiol Infect. p. 27-46, 2014.

108.Nucci M, Marr KA, Vehreschild MJGT, de Souza CA, Velasco E, Cappellano P, et al. Improvement in the outcome of invasive fusariosis in the last decade. Clin Microbiol Infect. v. 20, n.6. p. 580-5, 2014.

109.Campo M, Lewis RE, Kontoyiannis DP. Invasive fusariosis in patients with hematologic malignancies at a cancer center: 1998-2009. J Infect. v.60, n.5, p. 331-7, 2010.

110.Litvinov N, da Silva MTN, van der Heijden IM, Graça MG, Marques de Oliveira L, Fu L, et al. An outbreak of invasive fusariosis in a children's cancer hospital. Clin Microbiol Infect. v. 21, n.3, p. 1-268, 2015.

111.Hassler A, Lieb A, Seidel D, Cesaro S, Greil J, Klimko N, et al. Disseminated Fusariosis in Immunocompromised Children-Analysis of Recent Cases Identified in the Global Fungiscope Registry. Pediatr Infect Dis J. v. 36, n.2, p. 230-1, 2017.

112.Papadopoulos EB, Ladanyi M, Emanuel D, Mackinnon S, Boulad F, Carabasi MH, et al. Infusions of Donor Leukocytes to Treat Epstein-Barr Virus-Associated Lymphoproliferative Disorders after Allogeneic Bone Marrow Transplantation. NEngl J Med. v. 330, n.17, p. 1185-91, 1994.

113.Dominietto A, Tedone E, Soracco M, Bruno B, Raiola AM, Van Lint MT, et al. In vivo B-cell depletion with rituximab for alternative donor hemopoietic SCT. Bone Marrow Transplant. v. 47, n.1, p. 101-6, 2012.

114.Machado CM, Boas LS V., Mendes AVA, da Rocha IF, Sturaro D, Dulley FL, et al. Use of Oseltamivir to control influenza complications after bone marrow transplantation. Bone Marrow Transplant. v. 34, n. 2, p. 111-4, 2004.

115.Khawaja F, Chemaly RF. Respiratory syncytial virus in hematopoietic cell transplant recipients and patients with hematologic malignancies. Haematologica. v. 104, n.7. p. 1322-31, 2019.

116.Sim SA, Leung VKY, Ritchie D, Slavin MA, Sullivan SG, Teh BW. Viral Respiratory Tract Infections in Allogeneic Hematopoietic Stem Cell Transplantation Recipients in the Era of Molecular Testing. Biol Blood Marrow Transplant. v.24, n.7, p. 1490-6, 2018.

117. Machado C. Transplant Infections in Developing Countries. In: Bowden R, Ljungman $P$, Snydman D, editors. Transplant Infections. 3rd ed. Philadelphia: Lippincott Williams \& WIlkins; 2010. p. 90-103. 
118. Ramos JF, Batista MV, Costa SF. Tuberculosis in hematopoietic stem cell transplant recipients. Mediterr J Hematol Infect Dis. v. 5, n.1, 2013.

119.Maschmeyer G, Helweg-Larsen J, Pagano L, Robin C, Cordonnier C, Schellongowski P. ECIL guidelines for treatment of Pneumocystis jirovecii pneumonia in non-HIV-infected haematology patients. J Antimicrob Chemother. v. 71, n.9, p. 405-13, 2016.

120.Cordonnier C, Einarsdottir S, Cesaro S, Di Blasi R, Mikulska M, Rieger C, et al. Vaccination of haemopoietic stem cell transplant recipients: guidelines of the 2017 European Conference on Infections in Leukaemia (ECIL 7). Lancet Infect Dis. v. 19, n.6, p. 200-12, 2019.
121.Adati EM, da Silva PM, Sumita LM, Rodrigues $M$ de O, Zanetti LP, dos Santos ACF, et al. Poor response to hepatitis $A$ vaccination in hematopoietic stem cell transplant recipients. Transp/ Infect Dis. v. 22, n.3, p. 1-6, 2020.

122.Bastidas A, de la Serna J, El Idrissi M, Oostvogels L, Quittet P, López-Jiménez J, et al. Effect of Recombinant Zoster Vaccine on Incidence of Herpes Zoster After Autologous Stem Cell Transplantation: A Randomized Clinical Trial. JAMA.v. 322, n.2, p. 2019.

123. Machado CM, de Souza V a UF, Sumita LM, da Rocha IF, Dulley FL, Pannuti CS. Early measles vaccination in bone marrow transplant recipients. Bone Marrow Transplant. v.35, n.8, p. 787-91, 2005. 